Psychology of

Music

\title{
Scaffolding, organisational structure and interpersonal interaction in musical activities with older people
}

\begin{tabular}{|c|c|}
\hline Journal: & Psychology of Music \\
\hline Manuscript ID: & POM-12-404.R2 \\
\hline Manuscript Type: & Original Empirical Investigations \\
\hline Keyword: & $\begin{array}{l}\text { organisational structure, scaffolding, older learners, facilitators, community } \\
\text { music }\end{array}$ \\
\hline Abstract: & $\begin{array}{l}\text { The research reported here focuses on the organisational structure and } \\
\text { facilitator strategies observed in musical activities with older people. The } \\
\text { observations formed one part of the Music for Life Project, funded by the } \\
\text { ESRC New Dynamics of Ageing Programme } \\
\text { (http://www.newdynamics.group.shef.ac.uk/) which investigated the } \\
\text { social, emotional and cognitive benefits of participation in community } \\
\text { music making, amongst older people. } 398 \text { people aged } 50+, \text { were } \\
\text { recruited from three case study sites offering diverse musical activities. } \\
\text { Observations of } 33 \text { groups were analysed. Approximately half of the } \\
\text { observed time was spent with participants engaged in practical music } \\
\text { making, supported by facilitators who sang or played along, conducted or } \\
\text { accompanied. Facilitators spent a relatively small amount of time } \\
\text { providing non-verbal modelling and very little participant discussion or } \\
\text { facilitator attributional feedback was observed. The findings suggested } \\
\text { that facilitators could develop their practice by a) making more extensive } \\
\text { use of non-verbal modelling; b) creating space for open questioning and } \\
\text { discussion, where participants are encouraged to contribute to setting } \\
\text { goals; c) making more extensive use of attributional feedback that } \\
\text { empowers learners to control their own learning; and d) vary the } \\
\text { organisational structure and style in order to meet a range of diverse } \\
\text { needs within groups of older learners. }\end{array}$ \\
\hline
\end{tabular}




\title{
Scaffolding, organisational structure and interpersonal interaction in
} musical activities with older people

\begin{abstract}
The research reported here focuses on the organisational structure and facilitator strategies observed in musical activities with older people. The observations formed one part of the Music for Life Project, funded by the ESRC New Dynamics of Ageing Programme (http://www.newdynamics.group.shef.ac.uk/) which investigated the social, emotional and cognitive benefits of participation in community music making, amongst older people. 398 people aged 50+, were recruited from three case study sites offering diverse musical activities. Observations of 33 groups were analysed. Approximately half of the observed time was spent with participants engaged in practical music making, supported by facilitators who sang or played along, conducted or accompanied. Facilitators spent a relatively small amount of time providing non-verbal modelling and very little participant discussion or facilitator attributional feedback was observed. The findings suggested that facilitators could develop their practice by a) making more extensive use of non-verbal modelling; b) creating space for open questioning and discussion, where participants are encouraged to contribute to setting goals; c) making more extensive use of attributional feedback that empowers learners to control their own learning; and d) vary the organisational structure and style in order to meet a range of diverse needs within groups of older learners.
\end{abstract}

\section{Introduction}


A growing body of evidence has demonstrated the wider benefits, for older people, of engagement with active music making (for example, see Cohen et al., 2006; Creech et al., in press). However, the specific processes involved in fostering positive outcomes for participants have not been extensively researched. The overarching aim of the research that is reported here was to investigate the social, emotional and cognitive benefits of active participation in community music making amongst older people. The focus of this paper is the use of time in community music making activities for older people. An analysis of recorded observations of older people engaged in a range of musical activities is presented, with the objective of identifying facilitator strategies, organisational structure and interpersonal behaviours.

\section{Background}

There is now a significant body of literature concerned with the outcomes of music making amongst older people. There is some evidence, for example, that in the latter part of our lives participation in music may provide a source of enhanced social cohesion, enjoyment, personal development and empowerment (for example, Coffman, 2002; Sixsmith and Gibson, 2007; see Creech et al., in press, for a review). Some compelling evidence suggests that engagement with music continues to contribute to quality of life throughout the latter stages of the life-course, regardless of cognitive capacity (Cohen, Bailey and Nilsson, 2002) or musical background (Hays and Minichiello, 2005). Allison (2008) drew attention to the positive outcomes of group music-making amongst older people, fostered by facilitators who adopted a collaborative approach underpinned by a commitment to respecting the wisdom of the group and exploring the knowledge and insight of the participants. However, there has been little emphasis on the principles of pedagogy and approaches to the use of time in music-making with older people that may best support the aforementioned positive outcomes. 
Our understanding of facilitator strategies and use of time in musical contexts involving older people is, however, informed by the valuable work of several researchers who have, over the past three decades, investigated the use of time in musical contexts involving younger participants. This body of research has focused on teaching and rehearsal strategies and behaviours in classroom music contexts, band and choral rehearsals and one-to-one instrumental/vocal teaching contexts (see Rosenshine et al., 2002 and Hallam, 2006, for reviews).

Organisational structure: Cox (1989), for example, investigated the relationship between the organisational structure of choral rehearsals and student outcomes. Sixty secondary school choral directors and their students took part in the questionnaire study. Cox reported that a significant number ( $52 \%$ of the sample) of choral directors believed that efficient rehearsals were organised with fast-paced activities at the start and conclusion of sessions, with slower-paced, more detailed work attended to in the middle segment of the rehearsal. Others $(22 \%)$ preferred to organise rehearsals with a peak of intensity reached two thirds of the way through the session, while a further $25 \%$ said that they preferred rehearsal where fast and slow paced activities alternated regularly. However, positive student engagement was found in all three approaches and none of the chorus directors were negative about organisational structures that differed from their own. Cox concluded that a key point was that the directors had some kind of organisational strategy (as opposed to none) and that they were open-minded with regard to the possibility of altering their preferred approach, when appropriate. This is a salient point for facilitators of groups of older people, as it has been noted that as people accumulate life experience they become ever more diverse (Withnall, 2010), requiring flexibility on the part of group leaders.

In one-to-one contexts, effective music teaching was conceptualized by Yarbrough and Price (1989) as involving an organisational structure that comprised sequential units that began 
with teacher presentation of a task, followed by student response and engagement with the task and concluding with teacher feedback in relation to the student response. Siebenaler (1997) carried out an observational study, analyzing a total of 78 one-to-one piano lessons, half of which involved students aged 24+. A key finding was that long stretches of uninterrupted student performance 'often indicated a struggling student without appropriate teacher intervention' (Siebenaler, 1997, p. 17). Siebenaler concluded that expert teachers, in comparison with non-expert teachers, provided faster-paced sequences of instructionengagement-feedback, characterized by rapid alternation between teacher feedback and student response.

The specific organisation of time during instrumental (middle school and high school band) rehearsals was investigated by Goolsby (1996). Thirty band directors took part in the study, including ten who were rated as experienced, outstanding teachers, ten novice teachers and ten student teachers who had already completed five weeks of internship. For each of the participating teachers, two band rehearsals were observed and recorded. Goolsby reported that the experienced teachers, in comparison with the others, spent less time with initial teacher talk and verbal instruction, got the group on task more quickly, spent more time on warm-ups and in performance and made more use of non-verbal modelling. They also paced their rehearsals effectively, allowing sufficient time for each piece.

These studies suggest that the instruction-engagement-feedback sequence may be pervasive, regardless of student age, but raise questions with regard to whether the effectiveness of specific approaches to pacing and emphasis may differ with groups of older learners.

Scaffolding: The concept of scaffolding, whereby students are supported by knowledgeable others (including teachers, peers or parents) has been extensively researched in the wider context of education (for example, Needham and Flint, 2003). Scaffolding occurs when 
teachers provide appropriate support that enables students to move beyond their current skill or knowledge, in small and attainable steps. In order to maximize the potential for effective learning, instrumental students need teachers to scaffold their development in a range of 'aural, cognitive, technical, musical communication and performing skills' (Hallam, 2006, p. 169). In this vein, Colprit (2000) reported that expert teachers, conceptualized as those who accomplished positive change in their students' performances, structured their lessons in small attainable steps that led sequentially to the attainment of goals.

Kennel (2002) proposed that a typology of scaffolding comprising six stages proposed by Wood, Bruner and Ross (1976) could be applied in the context of instrumental learning. This would, in a musical context, include 1) recruitment strategies that synchronised the attention of student and teacher, 2) marking critical features of tasks, 3) manipulating the difficulty level of tasks, 4) modelling performance, 5) setting goals and 6) providing support for the student by engaging in dialogue intended to reduce frustration. He also proposed that in musical instruction, the type of scaffold employed by the teacher was always dependent upon the teacher's assessment of the student's performance, a phenomenon he labeled 'attribution scaffolding'.

Diagnostic skills and the use of modelling may both contribute to successful scaffolding in music. However, although some cultural differences in teacher and student behaviours have been noted (Benson and Fung, 2005), observational evidence from the USA (for example, Kennell, 1992) has suggested that large amounts of instrumental lesson time may be attributed to directive verbal diagnosis, with less time devoted to modelling. Kostka (1984) analysed 96 video recordings of individual piano lessons carried out by a total of 48 teachers, with students ranging from primary school-aged to retired seniors. Overall, approximately half of the observed lesson was spent in student performance, while the second largest chunk of time (42\%) was spent in directive teacher talk. 
The view that verbal diagnosis has an important role to play in scaffolding instrumental learning was supported by Salzberg (1980), who reported that university student string players produced more accurate intonation in response to verbal feedback than following modelled performance. Nevertheless, a substantial body of evidence supports the view that effective learning amongst instrumental students is supported when teachers model processes such as identifying difficulties and generating problem solving strategies, as well as when they model technical or musical aspects of desired performances (see, for example, Dickey, 1991, 1992; Kostka, 1984; Hallam, 2006).

An under-researched question is with regard to whether particular approaches to scaffolding may be most effective with groups of older learners, or whether, given the diversity that may be found amongst groups of older people, it may be the case that facilitators are most effective when they apply the full range of scaffolding strategies.

Use of feedback: The quality of teacher feedback has been the focus of much research concerned with teacher-student interaction. Praise, for example, has been found to be an effective and enduring form of scaffolding, but most notably when accompanied by physical, 'hands-on' corrective prompts. Salzberg and Salzberg (1981) carried out an experiment with five elementary school-aged violin pupils, comparing corrective feedback with praise. The researchers reported that praise was always as effective as corrective feedback and that when physical prompts were used in conjunction with praise, for extended periods, the effects were positive and sustained.

There is a wealth of empirical evidence in many diverse educational contexts to support the view that students who develop sustained and deep engagement in a given domain are supported in making attributions for success to effort and the correct use of learning strategies (Fryer and Elliot, 2008). In a musical context Colprit (2000) and Duke and Henninger (2002) 
have noted that the quality of teacher talk may distinguish expert teachers from their lessexpert counterparts. In particular, expert teachers have been found to provide specific attributions for student performance on tasks, for example making detailed reference to tone quality, intonation, expression, phrasing or articulation.

Duke and Henninger (1998) carried out an experimental study, focusing on verbal directions and feedback offered by recorder teachers. The study involved sixth-grade and college-aged students and compared a) a directive method, focusing on commands describing how the student should perform in a subsequent attempt, with b) a negative feedback method, focusing on identifying performance errors followed by directions for correcting the performance. In both conditions the recorder students had frequent opportunities to respond, the rate of teacher feedback was high and, where negative evaluations of previous attempts were offered by the teacher, these were accompanied by specific corrective feedback. The researchers reported that the novice recorder players had positive attitudes about having successfully achieved their musical goals and demonstrated high self efficacy, irrespective of the teaching approach. The researchers concluded that the salient factor that underpinned positive student experience had been the successful accomplishment of music goals, supported by specific (directive or negative) feedback.

In a follow-up study, Duke and Henninger (2002) investigated 51 trainee teachers' perceptions of the recorder lessons, testing whether the directive or negative feedback conditions influenced perceptions of the effectiveness of the recorded lessons. The trainee teachers rated both types of lessons highly positively and again the researchers reported that the feedback condition did not influence perceptions of positive experiences of learning. Expert teachers, according to the findings from this study, gave both positive and negative feedback at high rates, offering students many opportunities to respond to specific feedback and make improvements in their performance tasks. 
In summary, the evidence from observational studies in musical contexts strongly suggests that effective learning in musical contexts is supported when teachers implement a range of scaffolding strategies, including specific, honest and positive feedback and verbal diagnosis accompanied by high quality modelling and hands-on corrective prompts (for example, Colprit, 2000; Hallam, 2006; Kennell, 2002).

As noted above, there is little existing research specifically concerned with how music leaders might most effectively facilitate musical activities for older learners. However, many lessons may be learnt from the issues that have been highlighted in the wider educational gerontology literature. For example, research concerned with teaching older learners in a variety of domains (Duay and Bryan, 2008; Hickson and Housley, 1997; Villar et al., 2010), suggests that the interpersonal qualities, teaching strategies, skills and knowledge of group leaders and teachers may be more important, in some cases, than the content itself. Qualities that have been identified as contributing to positive outcomes for participants include enthusiasm, respect for participants, clarity and organisation, interest in participants' prior knowledge, subject knowledge and the ability to respond to diverse needs within a group.

Duay and Bryan (2008) explored conceptions of effective learning experiences. In-depth interviews were carried out with 36 seniors (mean age 76) involved in educational programmes for seniors. The interviewees suggested that effective facilitators employed a range of strategies to spark interest and sustain motivation, highlighting in particular the value of an open style of questioning, time for discussion and social interactions and time for practising new skills.

Withnall and Percy (1994) suggest that the role of facilitators is to discover what participants wish to achieve and to consider how to provide an enabling physical and psychosocial environment that meets these goals. Such an environment needs to be one where participants 
take responsibility for their learning, bring their own insights and contribute to developing individual and collaborative goals. Again, Withnall and Percy emphasize that it is crucial that an atmosphere of respect and trust is established, whereby it is recognized that learning is ultimately enriched by social interactions as well as individual contributions.

When one considers the compelling evidence that demonstrates the potential for music to support social, emotional, physical and cognitive well-being (Cohen et al., 2006; Creech et al., submitted), there is a clear rationale for research that contributes to our knowledge with regard to the specific uses of time and interpersonal processes in music-making with older people. This paper presents an analysis of recorded observations of older people making music in community settings. The analysis reported here formed one part of a larger project (Hallam et al., 2011) that investigated the social, emotional and cognitive benefits of participation in musical activities, amongst older people. Overall, Hallam et al. (2011) reported that older people who participated in community music activities felt that they had greater control over their lives, had more pleasure and felt more cared for than those who did not have access to musical activities. The specific nature of the wider benefits of these observed musical activities have been reported elsewhere (Hallam et al., submitted; Varvarigou et al., in press; Creech et al., submitted; Hallam et al., 2011). This paper focuses on the processes that were observed in the music-making, paying particular attention to facilitator style, interpersonal behaviour and organisational structure. The key questions that are addressed are a) what do facilitators do in practice, as leaders of music-making with older people, and b) does this differ in any substantive way from teaching styles and use of time with younger participants, that has been reported in previous research concerned with the use of time amongst directors of musical activities?

\section{Methods}


The observations that form the focus of this paper took place within the context of a larger research project that investigated the social, emotional and cognitive benefits of participation in community supported music-making amongst older people (Hallam et al., 2011). The aims of the project were: 1) to explore the ways in which participating in creative music making could enhance the lives of older people; 2) to consider the extent to which active engagement with music-making influenced social, emotional and cognitive well-being; and 3) to explore the specific process through which any such impact would occur. The research was undertaken using mixed methods including quantitative measures of well-being, individual interviews with participants and facilitators, focus groups with participants and observations of group music-making. The findings reported in this paper are related to the third aim, focusing on the observed use of time in music-making activities with the older people.

Participants in the research: Three case study sites acted as partners in the research: The first was the Sage, Gateshead, where an extensive programme of choirs and instrumental groups facilitated by community musicians was offered to seniors. Some groups took place in the Sage, Gateshead, an iconic arts centre/concert hall, while others took place in outreach locations around the wider area. The second case study site was the Music Department of the Westminster Adult Education Service, a more formal adult learning context offering choirs, music appreciation classes and keyboard classes. Finally, the Connect programme at the Guildhall School of Music offered creative intergenerational music workshops within sheltered housing centres, delivered by facilitators who had been trained as community outreach music leaders. Overall, the musical activities engaged with included singing in small and large groups, rock groups, and classes for guitar, ukulele, steel pans, percussion, recorder, music appreciation and keyboard. A 'non-music' comparison group was made up of individuals attending language classes (4 groups); art/craft classes (5 groups); yoga; social 
support (2 groups); a book group; and a social club. The findings reported in this paper are concerned only with observations of the music groups.

Eighty percent of the musical group sample was female and the majority was white. Despite attempts to recruit participants from a range of ethnic minority groups, such groups were not well represented in the case study populations. The age range was 50-93 with 246 members of the music participants aged 50 - 75 and 92 aged over 75 (60 did not state their age). The majority of those participating in the music groups had been involved in professional occupations and $76 \%$ had some kind of prior musical experiences. Twenty-nine percent classed themselves as musical beginners. Only $4 \%$ described themselves as 'very good', while the remainder described themselves as either average or good. Seventy three percent indicated that they could read music but for most this was at a basic level. Only $8 \%$ reported that they had 'very good' reading skills.

\section{Observations of the musical activities}

Twenty-three musical group activities were observed and digitally recorded using flipcameras, while a further ten were observed but not recorded. Field notes were taken during all of the observations. All participants, including facilitators and participants in the groups, provided verbal informed consent for the observations.

\section{Recorded Observations}

The recorded observations comprised randomly selected segments of group activities, of varying lengths. In total there were 53 recorded segments from 23 group activities (Table 1).

Table 1: Number of recorded segments of musical activities, according to type of activity HERE 
Table 2 sets out the number of recorded segments of musical activities at each site. The length of these recorded segments varied considerably. For example, at WAES there were four long segments, with a minimum of 1121 seconds and a maximum of 3583 seconds. In contrast, at the other sites there were more numerous shorter segments of recorded activities, with some as short as 32.9 seconds (Guildhall Connect). On average, the mean number of seconds in a recorded segment was 2008 at WAES, contrasting with 669 at Guildhall Connect, 494 at the Sage, Gateshead and 322 at the Guildhall Connect intergenerational project. In total, the greatest amount of recording took place at the Guildhall Connect sessions (10709 seconds in total), while the least amount of recorded observation was at the Sage, Gateshead (7410 seconds).

\section{Table 2: Number and length of recorded segments of musical activities at each site} HERE

The total amount of recorded observation time (in seconds) amongst the different types of groups is set out in Figure 1. The singing and percussion group (Guildhall Connect 'creative workshops') had the greatest amount of recorded time; this reflects the fact that the project researchers visited these groups on a weekly basis, assisting with management of the groups. In contrast, the groups located at WAES and the Sage, Gateshead were visited periodically during the project (five visits spread over the ten months of music-making). While the Sage, Gateshead and Westminster Adult Education Service (WAES) activities included a range of both choral and instrumental groups, the Guildhall Connect 'creative workshops' included two specific groups where the activities included singing, song writing and experimentation with un-tuned percussion instruments. One music appreciation group at WAES included listening activities as well as discussion, singing and hands-on experimentation with world instruments that had been brought in to the session. Because of the practical singing and 
'hands-on' element of this group it was decided that this activity could be described as 'active' rather than 'passive' engagement in a musical activity.

\section{Figure 1: Total amount of recorded observation time (in seconds) amongst different types of group HERE}

\section{Analysis of the recorded observations}

Two researchers analysed the recorded observations. A coding scheme for the various behaviours was developed, based on the observed activities and behaviours. Each recorded segment was watched three times. On the first viewing, behaviours and activities were noted and agreed between the two researchers (Table 3). Because the groups varied considerably with regards to the type of music-making, the researchers took the decision to create one overarching category of 'scaffolding' that encompassed supportive facilitator strategies such as conducting, accompanying and singing or playing along with participants. While modelling and verbal diagnosis have been conceptualized as forms of scaffolding (Kennell, 2002) other researchers have drawn particular attention to the time spent engaged with these specific behaviours (Dickey, 1992; Kostka, 1984; Salzberg, 1980). For the purposes of the analysis undertaken here, it was decided that both modelling and verbal diagnosis could be observed across the differing types of music-making contexts and should be treated as separate categories, distinct from scaffolding.

\section{Table 3: Coding scheme for recorded observations}

\section{HERE}

The recorded segments were subsequently analysed twice, the first time focusing on participants and the second time focusing on facilitators. The observational analysis software 
tool SCRIBE $4.0^{1}$ was used; this software made it possible to record the number of times each behaviour was observed as well as the duration (in seconds) of each occurrence. As the recorded segments were not of a consistent length, the findings presented here will focus on the percentage of total observation time coded at each category.

\section{Results}

Overall, the greatest amount of time was coded as 'scaffolding' for facilitators and 'music making and practical work' for participants. Scaffolding included 1) conducting, 2) accompanying and 3) singing or playing along with participants. For the purposes of this analysis, modelling was treated as a separate category. Table 4 sets out the categories of behaviour that were noted in the observed recordings, showing the mean percentage of total recorded time and the standard deviation, for each behaviour category. Facilitators used modelling on average approximately $15 \%$ of the time, in comparison with approximately $48 \%$ of time spent conducting, accompanying or singing/playing along with participants. On average, nearly $10 \%$ of facilitator time was coded as 'organisational activity', referring to tasks such as organising the space, setting out chairs, handing out music, preparing instruments. Facilitators spent, on average, a further $6 \%$ of time diagnosing the participants' musical performance, providing explanations and answering questions, $5 \%$ of time asking questions and $4 \%$ of time directing the groups in a non-negotiable manner.

Amongst participants, nearly $30 \%$ of time (on average) was spent listening passively to directions, explanations and modelling, with a further $10 \%$ of time (on average) spent in a range of physical (e.g. stretching, breathing) and vocal (e.g. humming, scales, tone

\footnotetext{
${ }^{1}$ See http://cml.music.utexas.edu/online-resources/scribe-4/description/
} 
production) warm-up activities. A small amount of participant time was coded as asking questions, discussing or offering their own opinions.

The facilitators provided very little negative feedback. Slightly more time was spent providing positive feedback, with more positive feedback of the non-attributional type (e.g. 'Good', 'Well done') than the attributional type (i.e. attributing good outcomes to specific strategies).

Table 4: Overall mean percentage of time for each behaviour HERE

There were some evident differences in the use of time, across the different types of groups. For example, Table 5 shows that in the intergenerational music sessions an average of $17 \%$ of time was coded as 'warm-up activities', compared with just 3\% of time in the instrumental groups and $7 \%$ of time in the choirs. Table 5 suggests that the participants spent greater amounts of time in active music making and practical activities within the instrumental groups than in the other groups, while there was the most group discussion in the choirs. It is interesting to note that in the music appreciation class there was more time coded as 'participants offer own opinions' than the other groups, but no time coded as 'discussion'. This may suggest that while a few participants were vocal and contributed their own ideas, the group as a whole was not facilitated in developing a group discussion.

Table 5: Mean percentage of time coded for participant behaviours, comparing types of group HERE

There were also some evident differences amongst the facilitators, in relation to how they used their time. Table 6 suggests, for example, that facilitators for the intergenerational singing/instrumental group spent more time asking questions than those who facilitated other 
groups. The choir facilitators seemed to provide the most feedback, of both the attributional and non-attributional types. There was very little use of modelling in the intergenerational group. While the creative workshop facilitators did use modelling fairly extensively, they made less use of other forms of scaffolding such as singing and playing along, accompanying and conducting, compared with the instrumental ensembles and choirs. The facilitator of the music appreciation group made some use of scaffolding and modelling, particularly when the group was exploring some world music instruments that had been brought in for the session. However, as might be expected due to the nature of the group, there was less active practical work on the part of the facilitators or the participants, in comparison with the other groups.

\section{Table 6: Mean percentage of time coded for facilitator behaviours, comparing types of group HERE}

\section{Statistical tests for differences between the different types of group}

A one-way between-groups multivariate analysis of variance was performed to investigate differences between the types of group with respect to use of time within the observed musical activity sessions. The percentages of time coded at each of the 16 behaviour categories noted above in Table 2 were entered as dependent variables. The independent variable was 'type of group'. Preliminary assumption testing revealed a potential violation of the assumption of homogeneity (this was due to the inconsistency in the length of the individual recorded segments, as noted above in Table 2); therefore, Pillai's Trace statistic was used, as recommended by Pallant (2007). There was a statistically significant difference between the types of group on the combined dependent variables, $F(48,108)=2.08, p<$ .001 ; Pillai's Trace $=1.92$; partial eta squared $=0.48$. When the results for the dependent variables were considered separately, statistically significant $(\mathrm{p}<.05)$ differences were revealed for 'participant asking questions' $(\mathrm{p}=.01)$, 'facilitator scaffolding' $(p=.05)$ and 
'facilitator organisation $(p=.03)$. None of these differences reached the level of statistical significance $(p=.003)$ required when the Bonferroni adjustment for avoiding Type 1 errors was taken account of, as recommended by Pallant (2007).

\section{Statistical tests for differences between the case study sites}

A further one-way between-groups multivariate analysis of variance was performed to investigate differences between the case study sites with respect to use of time within the observed musical activity sessions. As with the analysis for differences amongst types of group, percentages of time for each of the 16 coded behaviour categories were entered as dependent variables. The independent variable was 'case study site', with the Guildhall Connect intergenerational project being treated as a fourth case study, separate from the Guildhall Connect creative workshops with older people only. As with the analysis of differences between types of group, Pillai's Trace statistic was used (Pallant, 2007). There was a statistically significant difference between the case study sites on the combined dependent variables, $F(48,108)=3.49, p<.001$; Pillai's Trace $=1.82$; partial eta squared $=$ 0.61. When the results for the dependent variables were considered separately, statistically significant $(p<.05)$ differences were revealed for 'facilitator diagnosis' $(\mathrm{p}=.03)$, 'facilitator modelling' ( $\mathrm{p}=.01)$, 'facilitator scaffolding' $(p=.02)$, 'facilitator organisation' $(p=.01)$ and 'participant asks questions' $(p=.003)$. Only one of these differences (participant asks questions) reached the level of statistical significance $(p=.003)$ required when the Bonferroni adjustment is made to avoid Type 1 errors, as recommended by Pallant (2007). Participants were observed asking questions for the greatest amount of time within the context of the music appreciation class and the choirs, while very little time was coded as 'participant questions' in the intergenerational or creative workshops.

\section{Observation field notes}


Field notes were taken during all of the observations. In addition to the recorded observations discussed above, field notes were taken during observations of un-recorded activities that included creative workshops, choirs, steel pan, recorder, ukulele, guitar and rock groups. Table 7 sets out a summary of the field notes, suggesting some similarities and differences between the groups in relation to their focus, content, facilitator style and interpersonal climate. For example, while the creative workshop sessions focused on transferable skills such as listening, watching and copying, coordination and (in particular) memory, the choral and instrumental groups placed more of an emphasis on specific musical skills such as intonation, tone quality and note reading.

In all of the different types of groups positive peer interactions were noted, with some groups offering each other emotional support while others engaged in peer learning (most obvious in the instrumental groups) and celebrated their musical achievements as a group. However, there was also evidence of some negative peer interactions. For example, some participants were critical of others who did not integrate with the group. In some cases, where there had been negative interactions outside of the musical group, these were brought in to the group. Some minor negative interactions related to instances when group members disliked seating arrangements, felt the level of musical activity was not appropriate for them personally or when they disliked the choice of repertoire. Overall, though, these negative interactions were rare.

The style of facilitation varied from group to group. Particularly in the choirs, facilitators made extensive use of humour, creating an informal atmosphere within the framework of structured sessions. Some facilitators, for example in the rock group, functioned as fellow members of the group, sharing decision making and responsibility for feedback with 
participants. Others were semi formal, facilitating participants in experimenting with new skills and encouraging peer learning. Still others were more directive, following a structured plan for the group session. The pace of the sessions also varied considerably. Some sessions tended to have a slower pace than others, with much time spent on warm-ups and in organisational tasks such as distributing percussion instruments and arranging seating.

\section{Table 7: Summary of field notes}

\section{HERE}

\section{Discussion and Implications}

Access to opportunities for engagement in later life learning and participation in music is not, on its own, enough to ensure that the potential for physical, social, emotional and cognitive benefits (Cohen et al. 2006, Hallam et al., 2011) is maximised. Practitioners need to understand how time may most effectively be organised and may need training and guidance with regards to how age related issues may most effectively be addressed.

In accordance with earlier observational research in music that has focused on young musicians learning in one-to-one contexts (Kostka, 1984), this analysis of the use of time in group music-making with older people suggested that typically, approximately half of the music session time was spent in 'performance' - active music making or practical activities where the facilitator accompanied the participants, played along (instrumental groups) or sang together with them. The fact that 'performance' time nearly always involved collaboration, with facilitators and participants engaging in music-making together would suggest that this is a positive finding rather than, as Siebenaler (1997) observed in the context of young musicians learning in one-to-one settings, indicating struggling students engaging in long uninterrupted performance episodes. 
While the facilitators made extensive use of the scaffolding strategies that could be said to correspond with Kennel's (2002) notion of modeling performance and synchronizing attention (playing along, singing along, conducting, accompanying), other aspects of scaffolding such as engaging in dialogue, marking critical features or setting goals were, overall, less prevalent. Kennel (2002) proposes that in studio instrumental lessons scaffolding strategies are typically 'linked to the teacher's understanding of the student's performance' (p. 246). Withnall and Percy (1994), however, remind us that older learners flourish within environments where their insights are valued and where there is scope for facilitators and participants to work together in establishing collaborative goals. In this vein, positive outcomes for older participants within musical settings may be enriched when facilitators develop interactive scaffolding strategies. One way of approaching this could be for facilitators to make more use of open questions, eliciting analytical responses from participants. This was one area of practice where there was significant variability amongst the observed groups

Non-verbal modelling was found to account for a relatively small percentage (approximately $15 \%$ ) of time. Previous research has demonstrated the effectiveness of a range of scaffolding approaches. In particular the effectiveness of non-verbal modelling has been noted (Dickey, 1991; 1992; Goolsby, 1996; see Hallam, 2006 for a review). This would suggest that more extensive use of modelling is one area where facilitators might develop their practice in order to meet the diverse needs that might be found within a group of older learners. With older learners, this may be most effective when integrated as peer support activities and interspersed with many opportunities for participants to practise new skills, as suggested by Duay and Bryan (2008).

In contrast with observational studies involving younger participants (Kostka, 1984; Goolsby, 1996), 'teacher talk' was not predominant in the sessions with older participants. Verbal input 
from facilitators accounted, in total, for less than $20 \%$ of the recorded observation time. Again, this may be interpreted as a positive finding; as Goolsby (1996) suggested, expert teachers may make less use of verbal instruction than non-experts.

Much of the verbal input observed in the research reported here took the form of diagnosis, explanation and asking or answering questions. A very small amount of negative feedback was observed, either of the attributional or non-attributional variety. Rather, feedback tended to be positive; this tended to take the form of non-attributional positive feedback such as 'well done' or 'good'. Facilitators could reflect and develop their practice with regard to this point, as specific, attributional feedback has been shown to be a highly effective strategy for engaging learners in music (Colprit, 2000; Dukie and Henninger, 1998; 2002) and is associated with the theory that specific attributions support learners' motivation to understand and master their environment (see chapter 3 in Schunk, Pintrich and Meece, 2010). Indeed, with regard to older learners, the provision of specific, corrective feedback may be a crucial feature of 'enabling' learning and teaching environments where older people take responsibility for their learning (Withnall and Percy, 1994).

The observed music sessions varied considerably in organisational structure and pace. For example, in the rock group the facilitator adopted a 'fellow traveller' approach (Jones, 2005), rehearsing and exploring the music alongside the participants. This contrasted with more formal approaches where sessions were highly facilitator-led. Within the more formal approach there was also diversity in facilitator style, with some making extensive use of humour in order to reduce anxiety and establish an informal 'feel', while others pursued a highly structured plan. Cox (1989) drew attention to the importance of organisational structure and made the salient point that effective music sessions needed to have some kind of organisational structure, but that the most important thing was that facilitators were flexible with regard to structure. In the context of music making with older people this is an 
important point. Facilitators need to be equipped with a repertoire of strategies and organisational approaches so that they may be empowered to take decisions with regard to which approach will be most appropriate and most effective for any given group.

\section{Methodological limitations and implications}

The analysis presented here is based on randomly selected extracts of group music-making amongst older people. A limitation of the study is that the extracts were not all at the same point in each session and were not all of the same length. Future research is needed that would examine issues of pacing with a systematic approach to the time segments to be analysed, for example extracting the first ten minutes of each session, ten minutes at the midpoint and ten minutes at the conclusion. Furthermore, while inter-rater reliability in the analysis presented here was achieved through two researchers engaging in repeated viewings of the recorded extracts and discussion, future research may establish further depth and nuance in the interpretation by involving the older people and their facilitators in the process of analysis. This would be in accordance with the principles set out by Withnall (2010, p.

119) who reminds us that amongst our diverse older population it is the older people themselves who are best place to tell us about 'the relative effects of different influences on individuals at different times'. Collaborative work with facilitators in action research where they could have an opportunity to reflect upon and interpret their own practice would also contribute significantly to enhancing practice in this area and could function as a tool for professional development.

\section{Conclusion}

By definition, any attempt to draw up a list of recommendations for facilitating groups of older people in music runs the risk of subscribing to the myth of that all older learners are the same (Findsen, 2005) or indeed that all musical groups require the same approach. Withnall 
and Percy (1994) caution that any prescriptive statements about older learners risk underestimating the rich diversity to be found amongst our older population. However, the despite the diversity of groups represented within this analysis, there were some similarities, suggesting that it may be possible to generate some broad principles that may support effective practice, drawing on a range of contrasting contexts. Overall the findings suggest that a wide repertoire of scaffolding strategies and organisational approaches may support facilitators in developing musical activities that foster the positive benefits of music and learning that have been demonstrated elsewhere (Hallam et al., 2011). In particular, facilitators may develop their practice with older participants by a) making more extensive use of non-verbal modelling, encouraging this as a form of peer support and allowing many opportunities for individuals to practise new skills; b) creating space for open questioning and discussion, where participants are encouraged to offer their own insights and to contribute to setting collaborative and individual goals; c) making more extensive use of attributional feedback that empowers learners to understand and control their own learning; and d) vary the organisational structure and style in order to meet a range of diverse needs within groups of older learners. 


\section{References}

Allison, T. A. (2008). Songwriting and transcending institutional boundaries in the nursing home. In B. D. Koen (Ed.), The Oxford handbook of medical ethnomusicology (pp. 218-245). New York: Oxford University Press.

Cohen, A., Bailey, B., \& Nilsson, T. (2002). The importance of music to seniors. Psychomusicology - A Journal of Research in Music Cognition, 18(1-2), 89-102.

Benson, C., and Fung, C. V. (2005). Comparisons of teacher and student behaviors in private piano lessons in China and the United States. International Journal of Music Education, 23(1), 63-72.

Coffman. (2002). Music and quality of life in older adults. Psychomusicology, 18(Spring/Fall), 76-88.

Cohen, G. D., Perlstein, S., Chapline, J., Kelly, J., Firth, K. M., and Simmens, S. (2006). The impact of professionally conducted cultural programs on the physical health, mental health, and social functioning of older adults. The Gerontologist, 46(6), 726-734.

Colprit, E. J. (2000). Observation and analysis of Suzuki string teaching. Journal of Research in Music Education, 48(3), 206-221.

Cox, J. (1989). Rehearsal organizational structures used by successful high school choral directors. Journal of Research in Music Education, 37(3), 201-218.

Creech, A., Hallam, S., Gaunt, H., Pincas, A., McQueen, H., and Varvarigou, M. (in press). The power of music in the lives of older adults. Research Studies in Music Education.

Dickey, M. R. (1991). A comparison of verbal instruction and nonverbal teacher-student modelling in instrumental ensembles. Journal of Research in Music Education, 39(2), 132-142.

Dickey, M. R. (1992). A review of research on modelling in music teaching and learning. Bulletin of the Council for Research in Music Education, 113(Summer), 27-40.

Duay, D., and Bryan, V. (2008). Learning in later life: What seniors want in a learning experience. Educational Gerontology, 34(12), 1070-1086.

Duke, R. A., and Henninger, J. C. (1998). Effects of verbal corrections on student attitude and performance. Journal of Research in Music Education, 46(4), 482-495.

Duke, R. A., and Henninger, J. C. (2002). Teachers' verbal corrections and observers' perceptions of teaching and learning. Journal of Research in Music Education, 50(1), $75-87$. 
Fryer, J. W., and Elliot, A. J. (2008). Self-regulation of achievement goal pursuit. In D. H. Schunk and B. J. Zimmerman (Eds.), Motivation and self-regulated learning (pp. 5376). New York: Lawrence Erlbaum Associates.

Goolsby, T. W. (1996). Time use in instrumental rehearsals: A comparison of experienced, novice, and student teachers. Journal of Research in Music Education, 44(4), 286303.

Hallam, S. (2006). Music psychology in education. London: Institute of Education, University of London.

Hallam, S., Creech, A., Gaunt, H., Pincas, A., McQueen, H., and Varvarigou, M. (2011). Music for life project: Promoting social engagement and well-being through community supported participation in musical activities: Final report. London: Institute of Education, University of London and Guildhall School of Music and Drama (funded by the ESRC New Dynamics of Ageing Programme).

Hallam, S., Creech, A., Gaunt, H., Pincas, A., Varvarigou, M., and McQueen, H. (submitted September 2011). Does active engagement in community music promote enhanced quality of life in older people? Psychology of Music.

Hays, T., and Minichiello, V. (2005). The contribution of music to quality of life in older people: An Australian qualitative study. Ageing and Society, 25(2), 261-278.

Hickson, J., and Housley, W. (1997). Creativity in later life. Educational Gerontology, 23(6), 539-547.

Kennell, R. (2002). Systematic research in studio instruction in music. In T. Colwell and C. Richardson (Eds.), The new handbook of research on music teaching and learning (pp. 243-256). New York: Oxford University Press.

Kostka, M. (1984). An investigation of reinforcements, time use, and student attentiveness in piano lessons. Journal of Research in Music Education, 32(2), 113-122.

Needham, D., and Flint, K. (2003). Uncovering the truth behind Vygotsky's cognitive apprenticeship: Engaging reflective practitioners in the 'master-apprentice' relationship. International Journal of Learning, 10, 847-861.

Pallant, J. (2007). Spss survival manual (3rd ed.). Maidenhead: Open University Press with McGraw-Hill Education.

Rosenshine, B., Froehlich, H., and Fakhouri, I. (2002). Systematic instruction. In R. Colwell and C. Richardson (Eds.), The new handbook of research on music teaching and learning (pp. 299-314). Oxford: Oxford University Press.

Salzberg, R. S. (1980). The effects of visual stimulus and instruction on intonation accuracy of string instrumentalists. Psychology of Music, 8(2), 42-49.

Salzberg, R., and Salzberg, C. (1981). Praise and corrective feedback in the remediation of incorrect left hand positions in elementary string players. Journal of Research in Music Education, 29(2), 125-133. 
Schunk, D., Pintrich, P., and Meece, J. (2010). Motivation in education. Upper Saddle River, New Jersey: Pearson Education Inc.

Siebenaler, D. J. (1997). Analysis of teacher-student interactions in the piano lessons of adults and children. Journal of Research in Music Education, 45(1), 6-20.

Sixsmith, A., and Gibson, G. (2007). Music and the wellbeing of people with dementia. Ageing and Society, 27(1), 127-145.

Varvarigou, M., Creech, A., Hallam, S., and McQueen, H. (in press). Bringing different generations together in music-making - an intergenerational music project in east london. International Journal of Community Music.

Villar, F., Celdrán, M., Pinazo, S., and Triadó, C. (2010). The teacher's perspective in older education: The experience of teaching in a university for older people in Spain. Educational Gerontology, 36(10), 951- 967.

Withnall, A. (2010). Improving learning in later life. Abingdon, Oxon: Routledge.

Withnall, A., and Percy, K. (1994). Good practice in the education and training of older adults. Aldershot, England: Ashgate.

Wood, D. J., Bruner, J. S., and Ross, G. (1976). The role of tutoring in problem solving. Journal of Child Psychology and Psychiatry, 17, 89-100.

Yarbrough, C., and Price, H. E. (1989). Sequential patterns of instruction in music. Journal of Research in Music Education, 37(3), 179-187. 
Table 1: Number of recorded segments of musical activities, according to type of activity

\begin{tabular}{|l|r|r|r|rr|r|}
\hline Type of group & \multicolumn{6}{|c|}{ case study site } \\
\cline { 2 - 7 } & WAES & $\begin{array}{c}\text { Guildhall } \\
\text { Connect }\end{array}$ & $\begin{array}{c}\text { The Sage } \\
\text { Gateshead }\end{array}$ & $\begin{array}{c}\text { Guildhall Connect } \\
\text { Intergenerational } \\
\text { Project }\end{array}$ & Total \\
\hline Choir & 2 & 0 & 7 & 0 & 9 \\
\hline Instrumental group & 1 & 0 & 8 & 0 & 9 \\
\hline Music appreciation & 1 & 0 & 0 & 18 & 18 \\
\hline $\begin{array}{l}\text { Intergenerational } \\
\text { singing and } \\
\text { instrumental }\end{array}$ & 0 & 0 & 0 & & 0 & 16 \\
\hline $\begin{array}{l}\text { Creative workshop: } \\
\text { singing and percussion }\end{array}$ & 0 & 16 & 0 & & 18 & 53 \\
\hline Total & 4 & 16 & 15 & & 0 \\
\hline
\end{tabular}

Table 2: Number and length of recorded segments of musical activities at each site

\begin{tabular}{|l|r|r|r|r|r|r|}
\hline Case study site & \multicolumn{1}{|c|}{$\begin{array}{c}\text { Number } \\
\text { of } \\
\text { recorded } \\
\text { segments }\end{array}$} & $\begin{array}{c}\text { Minimum } \\
\text { number of } \\
\text { seconds }\end{array}$ & $\begin{array}{c}\text { Maximum } \\
\text { number of } \\
\text { seconds }\end{array}$ & $\begin{array}{c}\text { Mean } \\
\text { number } \\
\text { of } \\
\text { seconds }\end{array}$ & $\begin{array}{c}\text { Std. } \\
\text { Deviation }\end{array}$ & $\begin{array}{c}\text { Total } \\
\text { number } \\
\text { of } \\
\text { recorded } \\
\text { seconds }\end{array}$ \\
\hline $\begin{array}{l}\text { Westminster } \\
\text { Adult Education } \\
\text { Service }\end{array}$ & 4 & 1121 & 3583 & 2008.25 & 1107.79 & 8033 \\
\hline Guildhall Connect & 16 & 32.9 & 2876 & 669.29 & 777.82 & 10709 \\
\hline $\begin{array}{l}\text { The Sage, } \\
\text { Gateshead }\end{array}$ & 15 & 124.7 & 1069 & 493.98 & 309.78 & 7410 \\
\hline $\begin{array}{l}\text { Guildhall Connect } \\
\text { Intergenerational } \\
\text { Project }\end{array}$ & 18 & 34.7 & 1509.4 & 321.91 & 352.42 & 5794 \\
\hline
\end{tabular}


Table 3: Coding scheme for recorded observations

\begin{tabular}{|l|l|}
\hline Subject & Behaviour or activity \\
\hline Facilitator & Scaffolding (conducting, accompanying, singing or playing along) \\
\cline { 2 - 3 } & Modelling \\
\cline { 2 - 2 } & Organisational activities \\
\cline { 2 - 2 } & Warm-ups \\
\cline { 2 - 2 } & Diagnosis, explanation, answer questions \\
\cline { 2 - 2 } & Ask questions \\
\cline { 2 - 2 } & Directive \\
\cline { 2 - 2 } & Attributional positive feedback \\
\cline { 2 - 2 } & Non-attributional positive feedback \\
\cline { 2 - 2 } & Attributional negative feedback \\
\cline { 2 - 2 } & Non-attributional negative feedback \\
\hline Participant & Music-making and other practical work \\
\cline { 2 - 2 } & Listening \\
\cline { 2 - 2 } & Offer own opinions \\
\cline { 2 - 2 } & Ask questions \\
\cline { 2 - 2 } & Warm-ups \\
\hline All & Discussion \\
\hline
\end{tabular}


Table 4: Overall mean percentage of time for each behaviour

\begin{tabular}{|l|r|r|}
\hline Behaviour & \multicolumn{1}{|c|}{$\begin{array}{c}\text { Mean } \\
\text { Percentage of } \\
\text { total recorded } \\
\text { time }\end{array}$} & Std. Deviation \\
\hline Facilitator uses scaffolding & 48.22 & 29.98 \\
\hline Participant music making and practical work & 47.48 & 30.86 \\
\hline Participant listening & 29.20 & 23.81 \\
\hline Facilitator uses modelling & 15.22 & 21.77 \\
\hline Organisational activities & 9.94 & 14.44 \\
\hline $\begin{array}{l}\text { Warm-up (Rubbing hands, arms, neck; } \\
\text { stretching; breathing exercises; vocal warm- } \\
\text { ups) }\end{array}$ & 9.77 & 22.97 \\
\hline $\begin{array}{l}\text { Facilitator diagnosis, explanation, answer } \\
\text { questions }\end{array}$ & & 8.81 \\
\hline Facilitator asks questions & 6.45 & 14.82 \\
\hline Directive facilitator & 4.95 & 6.37 \\
\hline Participant offers own opinions & 3.72 & 2.65 \\
\hline $\begin{array}{l}\text { Facilitator provides non-attributional positive } \\
\text { feedback }\end{array}$ & 2.59 & 5.28 \\
\hline All discussion & 2.57 & 5.67 \\
\hline $\begin{array}{l}\text { Facilitator provides attributional positive } \\
\text { feedback }\end{array}$ & 2.41 & 0.72 \\
\hline Participant asks questions & 1.58 & 0.21 \\
\hline $\begin{array}{l}\text { Facilitator provides non-attributional } \\
\text { negative feedback }\end{array}$ & & 0.13 \\
\hline $\begin{array}{l}\text { Facilitator provides attributional negative } \\
\text { feedback }\end{array}$ & 0.03 & \\
\hline
\end{tabular}


Table 5: Mean percentage of time coded for participant behaviours, comparing types of group

\begin{tabular}{|c|c|c|c|c|c|}
\hline \multirow{3}{*}{$\begin{array}{l}\text { Participant } \\
\text { behaviour }\end{array}$} & \multicolumn{5}{|c|}{ Type of group } \\
\hline & choir & $\begin{array}{l}\text { instrumental } \\
\text { group }\end{array}$ & $\begin{array}{c}\text { music } \\
\text { appreciation }\end{array}$ & $\begin{array}{c}\text { intergenerational } \\
\text { singing and } \\
\text { instrumental }\end{array}$ & $\begin{array}{c}\text { creative } \\
\text { workshop: } \\
\text { singing and } \\
\text { percussion }\end{array}$ \\
\hline & $\begin{array}{l}\text { Mean } \\
\% \text { of } \\
\text { time }\end{array}$ & $\begin{array}{l}\text { Mean \% of } \\
\text { time }\end{array}$ & $\begin{array}{l}\text { Mean \% of } \\
\text { time }\end{array}$ & Mean $\%$ of time & $\begin{array}{l}\text { Mean \% of } \\
\text { time }\end{array}$ \\
\hline $\begin{array}{l}\text { Participant } \\
\text { asks } \\
\text { questions }\end{array}$ & 0.83 & 0.57 & 1.23 & 0.00 & 0.12 \\
\hline Warm-up & 6.71 & 3.19 & 0.00 & 17.29 & 7.34 \\
\hline $\begin{array}{l}\text { Participant } \\
\text { music making } \\
\text { and practical } \\
\text { work }\end{array}$ & 45.45 & 62.11 & 14.22 & 44.33 & 46.00 \\
\hline $\begin{array}{l}\text { Participant } \\
\text { listening }\end{array}$ & 34.37 & 19.52 & 29.96 & 28.41 & 32.59 \\
\hline $\begin{array}{l}\text { Participant } \\
\text { offers own } \\
\text { opinions }\end{array}$ & 0.44 & 0.56 & 5.76 & 3.38 & 3.85 \\
\hline All discussion & 4.91 & 1.81 & 0.00 & 1.26 & 2.79 \\
\hline
\end{tabular}


Table 6: Mean percentage of time coded for facilitator behaviours, comparing types of group

\begin{tabular}{|c|c|c|c|c|c|}
\hline \multirow{3}{*}{$\begin{array}{l}\text { Facilitator } \\
\text { behaviour }\end{array}$} & \multicolumn{5}{|c|}{ Type of group } \\
\hline & choir & $\begin{array}{c}\text { instrumental } \\
\text { group }\end{array}$ & $\begin{array}{c}\text { music } \\
\text { appreciation }\end{array}$ & $\begin{array}{c}\text { intergenerational } \\
\text { singing and } \\
\text { instrumental }\end{array}$ & $\begin{array}{c}\text { creative } \\
\text { workshop: } \\
\text { singing and } \\
\text { percussion }\end{array}$ \\
\hline & $\begin{array}{l}\text { Mean } \\
\% \text { of } \\
\text { time }\end{array}$ & $\begin{array}{l}\text { Mean \% of } \\
\text { time }\end{array}$ & $\begin{array}{l}\text { Mean \% of } \\
\text { time }\end{array}$ & Mean $\%$ of time & $\begin{array}{l}\text { Mean } \% \text { of } \\
\text { time }\end{array}$ \\
\hline $\begin{array}{l}\text { Facilitator asks } \\
\text { questions }\end{array}$ & 0.31 & 3.51 & 1.40 & 10.40 & 2.46 \\
\hline $\begin{array}{l}\text { Facilitator } \\
\text { diagnosis, } \\
\text { explanation, } \\
\text { answer } \\
\text { questions }\end{array}$ & 5.76 & 7.35 & 0.00 & 2.52 & 11.16 \\
\hline $\begin{array}{l}\text { Facilitator } \\
\text { provides } \\
\text { attributional } \\
\text { positive } \\
\text { feedback }\end{array}$ & 0.25 & 0.32 & 0.00 & 0.76 & 4.05 \\
\hline $\begin{array}{l}\text { Facilitator } \\
\text { provides non- } \\
\text { attributional } \\
\text { positive } \\
\text { feedback }\end{array}$ & 4.67 & 1.90 & 0.86 & 2.32 & 2.15 \\
\hline $\begin{array}{l}\text { Facilitator } \\
\text { provides } \\
\text { attributional } \\
\text { negative } \\
\text { feedback }\end{array}$ & 0.09 & 0.04 & 0.00 & 0.00 & 0.00 \\
\hline $\begin{array}{l}\text { Facilitator } \\
\text { provides non- } \\
\text { attributional } \\
\text { negative } \\
\text { feedback }\end{array}$ & 0.17 & 0.00 & 0.00 & $V$ & 0.00 \\
\hline $\begin{array}{l}\text { Facilitator uses } \\
\text { modelling }\end{array}$ & 19.74 & 19.84 & 7.52 & 3.93 & 23.28 \\
\hline $\begin{array}{l}\text { Facilitator uses } \\
\text { scaffolding }\end{array}$ & 53.33 & 54.85 & 16.65 & 59.10 & 31.34 \\
\hline $\begin{array}{l}\text { Directive } \\
\text { facilitator }\end{array}$ & 2.55 & 1.57 & 3.49 & 0.42 & 9.32 \\
\hline $\begin{array}{l}\text { Organisational } \\
\text { activities }\end{array}$ & 1.14 & 4.84 & 0.00 & 17.72 & 9.63 \\
\hline
\end{tabular}


Table 7: Summary of field notes

\begin{tabular}{|c|c|c|c|}
\hline & $\begin{array}{l}\text { Creative workshop } \\
\text { (including } \\
\text { intergenerational } \\
\text { sessions) }\end{array}$ & Choir & $\begin{array}{l}\text { Instrumental } \\
\text { (steel pans; } \\
\text { calabash; recorder; } \\
\text { ukulele; guitar; } \\
\text { rock; keyboard) }\end{array}$ \\
\hline $\begin{array}{l}\text { Specific skills } \\
\text { focused on }\end{array}$ & $\begin{array}{l}\text { Listening, watching, } \\
\text { coordination; } \\
\text { memory; rhythm. }\end{array}$ & $\begin{array}{l}\text { Singing, listening, } \\
\text { reading from score, } \\
\text { articulation; } \\
\text { intonation; mood; } \\
\text { rhythm. }\end{array}$ & $\begin{array}{l}\text { Listening, } \\
\text { coordination, } \\
\text { collaboration; note } \\
\text { reading; tone quality; } \\
\text { intonation; rhythm }\end{array}$ \\
\hline Content & $\begin{array}{l}\text { Songs, use of simple } \\
\text { un-tuned percussion } \\
\text { instruments, body } \\
\text { percussion, creative } \\
\text { element: words into } \\
\text { rhythm. }\end{array}$ & $\begin{array}{l}\text { Choral rehearsal, } \\
\text { variety of songs } \\
\text { New material } \\
\text { (detail); } \\
\text { Performance of } \\
\text { known material. }\end{array}$ & $\begin{array}{l}\text { Warm-up; } \\
\text { Stretch; } \\
\text { New material; } \\
\text { Re-cap known } \\
\text { material }\end{array}$ \\
\hline Facilitators & $\begin{array}{l}\text { All the activities are } \\
\text { facilitator-led. } \\
\text { Facilitators offer help } \\
\text { with rhythms and } \\
\text { lyrics, when they } \\
\text { think it is needed. } \\
\text { Facilitators } \\
\text { improvise } \\
\text { accompaniments, on } \\
\text { their own instruments } \\
\text { (e.g. flute, cello) }\end{array}$ & $\begin{array}{l}\text { Sessions usually } \\
\text { clearly structured, } \\
\text { but informal. } \\
\text { Some facilitator-led, } \\
\text { some 'democratic' } \\
\text { style, with all } \\
\text { participants } \\
\text { contributing ideas. } \\
\text { Facilitator offers } \\
\text { specific feedback on } \\
\text { performance. } \\
\text { Explanations always } \\
\text { connected with } \\
\text { demonstration by the } \\
\text { facilitator. }\end{array}$ & $\begin{array}{l}\text { Facilitators are } \\
\text { informal (sometimes } \\
\text { in role of 'fellow } \\
\text { participant' and } \\
\text { sometimes in a } \\
\text { leadership role) and } \\
\text { responsive to the } \\
\text { needs/suggestions of } \\
\text { the participants. } \\
\text { Use of projector and } \\
\text { whiteboard for chord } \\
\text { symbols, note } \\
\text { patterns, note } \\
\text { reading. }\end{array}$ \\
\hline Peer interactions & $\begin{array}{l}\text { Participants do not } \\
\text { ask for help. } \\
\text { Participants support } \\
\text { each other, cheer } \\
\text { each other up when } \\
\text { individuals seem to } \\
\text { be 'down'. }\end{array}$ & $\begin{array}{l}\text { Choir applauding } \\
\text { when peers sing a } \\
\text { difficult phrase. } \\
\text { Lots of laughter. } \\
\text { Participants praise } \\
\text { each other. }\end{array}$ & $\begin{array}{l}\text { Participants ask for } \\
\text { help from each other } \\
\text { and from the } \\
\text { facilitator. Some } \\
\text { participants offer } \\
\text { explanations to their } \\
\text { peers. } \\
\text { Groups express }\end{array}$ \\
\hline
\end{tabular}




\begin{tabular}{|c|c|c|c|}
\hline & $\begin{array}{l}\text { Some negative peer } \\
\text { interactions (e.g. } \\
\text { arguments, critical of } \\
\text { each other) }\end{array}$ & & $\begin{array}{l}\text { satisfaction with } \\
\text { themselves when } \\
\text { they perform whole } \\
\text { pieces correctly. }\end{array}$ \\
\hline Warm-ups & $\begin{array}{l}\text { Body stretching; } \\
\text { Massaging finger } \\
\text { joints; } \\
\text { Breathing exercise; } \\
\text { Action song games; } \\
\text { Tongue twister } \\
\text { games; } \\
\text { Mouth stretching } \\
\text { exercise. }\end{array}$ & $\begin{array}{l}\text { Rubbing hands, } \\
\text { stretching, hug } \\
\text { oneself, reverse hug, } \\
\text { raise shoulders, } \\
\text { stretching (facilitator } \\
\text { models and does it } \\
\text { with the choir); } \\
\text { Singing warm-up: } \\
\text { each part sings a note } \\
\text { and they build up a } \\
\text { chord; } \\
\text { Articulation exercise } \\
\text { 'petite - coquette' } \\
\text { (choir repeats several } \\
\text { times). }\end{array}$ & $\begin{array}{l}\text { Chords; Scales; Tone } \\
\text { production; Physical } \\
\text { stretching. }\end{array}$ \\
\hline
\end{tabular}


Figure 1: Total amount of recorded observation time (in seconds) amongst different types of group

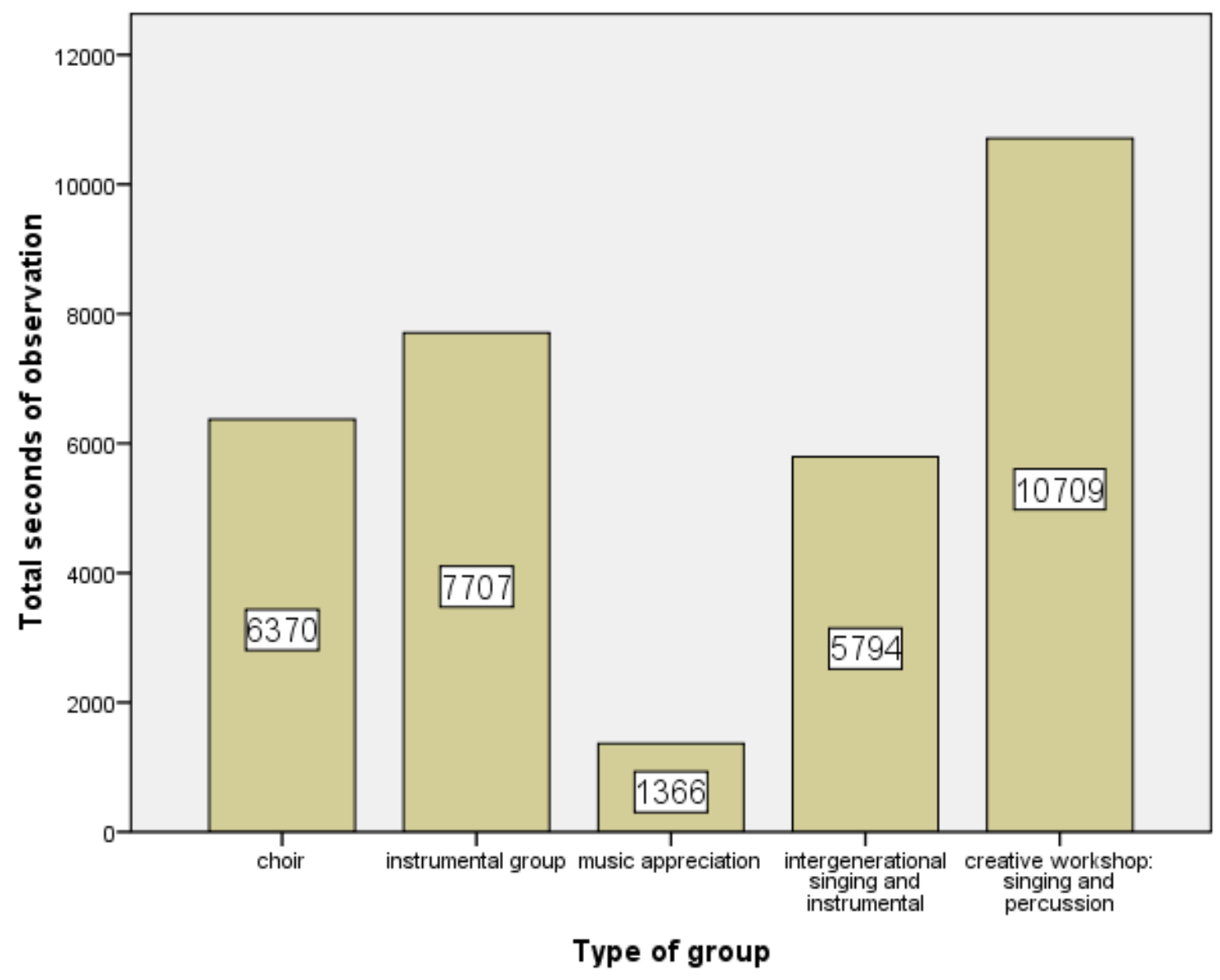

39

40 